\title{
Excavation in Julah's Temporary Settlement of Upit
}

\author{
I Ketut Setiawan and Rochtri Agung Bawono
}

\section{Introduction}

The northern part of Bali, especially the District of Tejakula, Buleleng Regency, encompassing the villages of Pacung, Sembiran and Julah, is a treasure trove of historical data such as prehistoric sites and inscriptions dating from the Bali Kuna (ancient Bali) era.

Further proofs of prehistoric civilization in this area are findings of a number of stone articles from the Palaeolithic Age in the Sembiran area such as: chopper, hand-adze, proto hand axe, core tool, hammer and scrapers (Soejono 1962). Another discovery is a terraced structure that may be similar to those in the megalithic age, upright stone and natural stones arranged in a pile. The terraced stone structure is believed to have been used as a site to pay homage to ancestors and to ask for safety and plenty for the living community (Sutaba 1976; 1980).

In the Classical Age Julah is mentioned in copperplate inscriptions of the Bali Kuna between the $10^{\text {th }}$ and $12^{\text {th }}$ centuries $A D$ written in the Bali Kuna or sometimes Java Kuna language (see Setiawan this volume). The inscriptions so far discovered amount to 20 pieces. Ten of them are kept in Sembiran and 10 in Julah (Goris 1954). The edicts contained in these inscriptions deal with the rights and the responsibilities of the people of Julah in relation to the kings of Bali Kuna (Brandes 1889). Based on the findings of these inscriptions, we can safely assume that the village life of Julah at that time was highly developed; Julah could even be 
considered a port town with its own representative market to conduct commerce (see Ardika this volume). As a port town Julah was visited by both local and foreign merchants that came to Julah in boats and ships and other (unknown) sea going vessels named as lancing and talaka (Santoso 1965).

Archaeological studies have only rarely been carried out in Julah with the exception of one systematic study in 1987. This excavation opened only one trench, Julah I (JLH I), with the discovery of a few earthenware fragments, Chinese ceramics and animal bone fragments. The find was concentrated at spit 9 and 10, or at the third layer (Ardika 1988; 1991).

The excavation at Julah was prompted by an interest in knowing the whereabouts of ancient villages described in the inscriptions found in Sembiran. The discovery of Chinese ceramic fragments in the hamlet of Batu Gambir in 1980 by local people raised hopes of finding archaeological data on Julah in the Bali Kuna age.

From an administrative point of view, the Batu Gambir excavation site is located in the village area of Julah, sub-district of Tejakula, Buleleng Regency, in hilly terrain. According to the local people, Batu Gambir was once the site of Julah's main temple, Pura Bale Agung (see Hauser-Schäublin this volume). The traditional term for this whole area is Upit, a name already mentioned in the copperplate inscriptions. Upit probably was a site where Julah's villagers fled to when they suffered attacks by enemies from the sea. Batu Gambir is a recent name given to the hamlet where today Muslim as well as Hindu immigrants from other parts of Bali live.

Batu Gambir (see Figure 1, Hauser-Schäublin this volume) sits on the crest of a hill with the west and east side falling steeply away into the rivers below. Julah is located on a flat strip of land near the coast. Today, the land of Julah's former refugee settlement is laba pura land (temple land) owned by the desa pakraman (core villagers) of Julah. The land is cultivated by growing cassava, nuts, bananas, mangoes, coconuts, avocados, rambutans, cloves, coffee beans and cocoa trees. The local community lives off this produce and from cattle farming.

Geologically, Julah is situated on the northern Bali mountain range, which is a part of the "Zone Solo" in Java. This is a volcanic range formed in the Pleistocene Age. Within this zone is found the Mount Batur complex, whose lava route runs in a northerly direction through Sembiran, Pacung, Julah, and Bondalem and through the rivers in that area (Poesponegoro and Notonegoro 1984).

According to the geological map of Bali - Nusa Tenggara, Julah shows two geological characteristics:

The formation Asah consisting of lava rocks, volcanic breccia and tuff stone, side by side with karst sediment.

The volcanic formation of the Buyan-Bratan-Batur mountain ranges from tuff and lava (Purbo-Hadiwidjojo et al. 1998). 
The Asah formation is located in lower Julah while the volcanic formation of the Buyan-Bratan-Batur group is in upper Julah.

On the basis of Bali's hydrogeology map, drawn to a scale of 1:250.000, Julah has a variety of water resources. The coast closer to lower Julah has local water resources with a spring discharge of $0.1 \mathrm{lit} / \mathrm{sec}$, located in the lava area. Upper Julah has local water resources with a spring discharge of 1 lit/sec (PurboHadiwidjojo 1971). The smaller water source is found to the east of Batu Gambir with a spring discharge of less than $10 \mathrm{lit} / \mathrm{sec}$ and is called the source of the Upit. This is a sacred well: the tirta (sacred water) is taken for religious ceremonies. East of Upit is a waterfall used by local people for their daily needs.

\section{The Archaeological Investigation}

The excavation at Batu Gambir Site in 2004 was the first made there. It would be important to know more about or to test the spit, i.e. about the general state of the structure and layers of the earth.

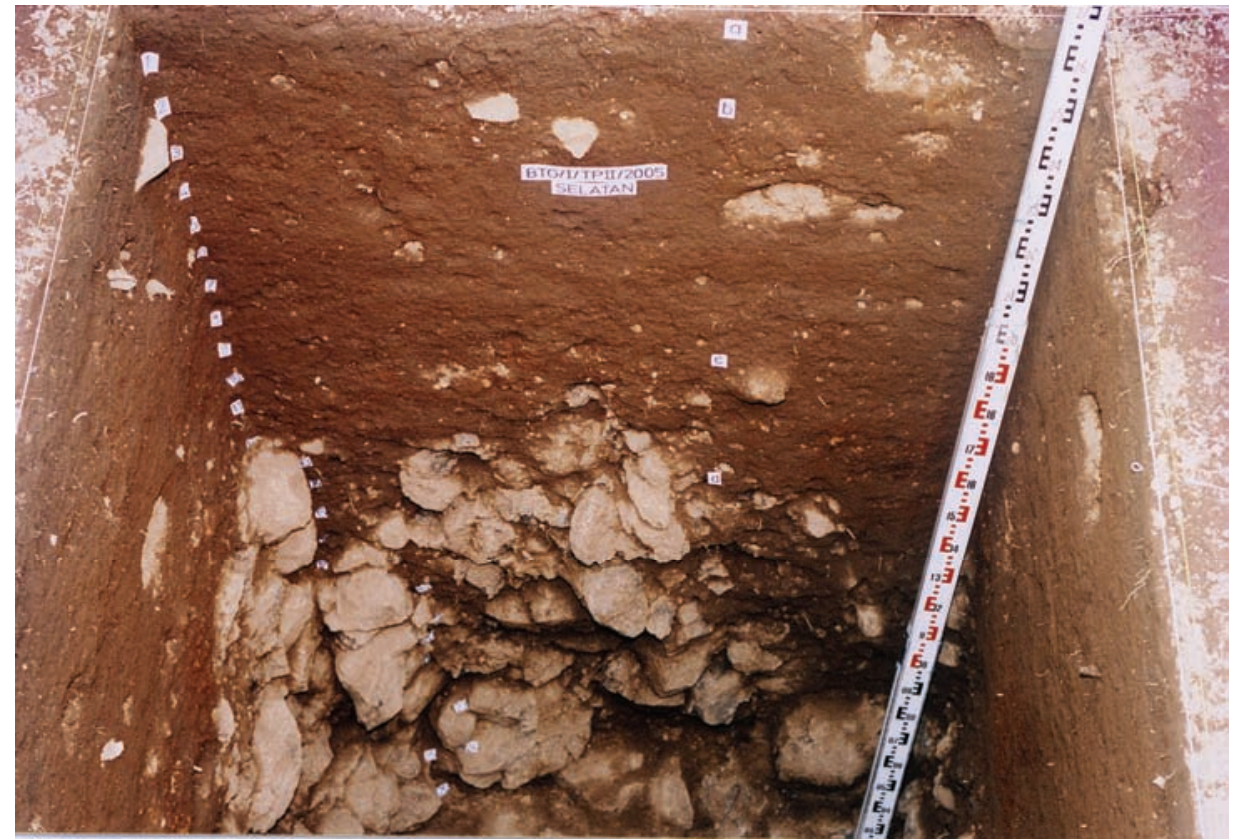

Photo 1: Test Pit II in Batu Gambir displaying the stratigraphy with a layer of stones at the bottom. Photo: Tim Jurusan Arkeologi 2005. 
The procedures and results of the excavation are as follows:

Square Test Pit (TP I)

Located approximately $378 \mathrm{~m}$ above sea level in the cultivated land owned by the Desa Pakraman Julah, approximately $400 \mathrm{~m}$ from Batu Gambir Mosque. The quality of the soil is good because the land is constantly cultivated by the people for planting.

The square is $1.5 \times 1.5 \mathrm{~m}$ and dug using the spit method with each spit $10 \mathrm{~cm}$ deep, excluding the first spit which is $15 \mathrm{~cm}$ in depth from the datum line (string level).

The condition of the soil has been identified as having four characteristic layers (from top down) as follows:

Humus/top soil, light brown with a yellowish tinge colour

Humus/top soil, brown blackish colour

Mixture of sand and tuff stone, brown colour

Mixture of volcanic stone and clay, brownish colour

Layer "a" is of humus/top soil down to about $15 \mathrm{~cm}$ in depth and is mostly cultivated and used for farming. Its texture is medium with a light brown yellowish tinge. Between $15 \mathrm{~cm}-40 \mathrm{~cm}$ in depth, the soil's texture is still medium but with a change of colour to brown blackish. Both can still be called humus but the difference is in the humidity of the soil. After a depth of $40 \mathrm{~cm}-60 \mathrm{~cm}$ the soil changes to rough, as it becomes a mixture of sand and tuff stone, brownish in colour.

At a depth of $60 \mathrm{~cm}-160 \mathrm{~cm}$ the soil condition changes to a mixture of volcanic stone and sand making its texture very coarse and brown in colour. The digging terminates at a depth of $170 \mathrm{~cm}$ volcanic rocks start.

Discovered at TP I have been: earthenware fragments, Chinese ceramics fragments, coal residue, coin fragments, animal bones and teeth fragments. Also fragments of pottery such as: lip, rim, carination, body and base from top spit to spit 13 with greater population at spit 5 to spit 9. Coal was found at spit 6, 8, 9, and 11 (see Table 1 below).

The greatest variety of items was yielded between spits 4 to 9 . 
Table 1: Items Found in TP I

\begin{tabular}{|c|c|c|c|c|c|c|}
\hline \multirow[b]{2}{*}{ Layer } & \multirow[b]{2}{*}{ Spit } & \multicolumn{5}{|c|}{ Result } \\
\hline & & $\begin{array}{c}\text { Earthenware } \\
\text { Fragment }\end{array}$ & $\begin{array}{c}\text { Ceramic } \\
\text { Fragment }\end{array}$ & $\begin{array}{l}\text { Bone } \\
\text { Fragment }\end{array}$ & $\begin{array}{l}\text { Coal Resi- } \\
\text { due }\end{array}$ & $\begin{array}{c}\text { Metal (coin) } \\
\text { Fragment }\end{array}$ \\
\hline \multirow{3}{*}{ A } & Surface & 24 & 3 & - & - & - \\
\hline & 1 & 29 & 3 & - & - & - \\
\hline & 2 & 30 & - & - & - & - \\
\hline \multirow{2}{*}{ B } & 3 & 11 & - & - & - & - \\
\hline & 4 & 24 & 1 & 1 & - & - \\
\hline \multirow{2}{*}{ C } & 5 & 50 & 2 & - & - & - \\
\hline & 6 & 41 & 3 & 1 & $2 \mathrm{~g}$ & $1 \mathrm{~g}$ \\
\hline \multirow{8}{*}{ D } & 7 & 61 & 2 & - & - & - \\
\hline & 8 & 64 & 2 & 1 & $20 \mathrm{~g}$ & $0.5 \mathrm{~g}$ \\
\hline & 9 & 52 & 1 & 1 & $2 \mathrm{~g}$ & - \\
\hline & 10 & 23 & 2 & - & - & - \\
\hline & 11 & 18 & 1 & - & $2 \mathrm{~g}$ & - \\
\hline & 12 & 26 & 2 & - & - & - \\
\hline & 13 & 4 & 2 & - & - & - \\
\hline & 14 & - & - & - & - & - \\
\hline \multicolumn{2}{|l|}{ Total } & 457 & 24 & 4 & $26 \mathrm{~g}$ & $1.5 \mathrm{~g}$ \\
\hline
\end{tabular}

\section{Square Test Pit (TP II)}

Located at approximately $375 \mathrm{~m}$ above sea level, $28 \mathrm{~m}$ north of square TP I. Soil condition can be said to be the same as in square TP I.

The trench is $1.5 \times 1.5 \mathrm{~m}$ and dug using the spit method with each spit $10 \mathrm{~cm}$ deep, excluding the first spit, which is $15 \mathrm{~cm}$ in depth from the datum line (string level). The dig goes down to $270 \mathrm{~cm}$ from the surface.

The condition of the soil has been identified as having four characteristic layers (from top down), as follows:

Humus/top soil, light brown colour

Sandy clay particles, brown colour

Mixture of clay and tuff stone, brown-reddish colour

Mixture of andesit, volcanic breccia, and clay layer, brownish colour

Layer "a", humus/top soil, is mostly cultivated to a depth of $20 \mathrm{~cm}$, light brown with yellow a tinge. From a depth of $20 \mathrm{~cm}-100 \mathrm{~cm}$ the soil condition changes to a sandy soil of brownish colour with a medium texture. Layer "c" is at a depth of $100 \mathrm{~cm}-130 \mathrm{~cm}$, the soil consisting of tuff stone, rough texture and brown to reddish in colour. 
Layer "d" is at a depth of $130 \mathrm{~cm}-270 \mathrm{~cm}$ and is a mixture of andesit and volcanic breccia. Digging stopped at this level because of the overall rocky condition, and no artefacts were found.

At TP II, between the top-most spit and spit 5 at $60 \mathrm{~cm}$ from string level, there were found earthenware fragments (lip, rim, and neck), Chinese ceramics fragments, coal residue and bone fragments. Earthenware was then uncovered at spit 24 (see Table 2).

Table 2: Items Found in TP II

\begin{tabular}{|l|l|l|l|l|l|l|}
\hline \multirow{3}{*}{ Layer } & \multirow{2}{*}{ Spit } & \multicolumn{6}{|c|}{ Result } \\
\cline { 3 - 8 } & & $\begin{array}{l}\text { Earthenware } \\
\text { Fragments }\end{array}$ & $\begin{array}{l}\text { Ceramic } \\
\text { Fragments }\end{array}$ & $\begin{array}{l}\text { Bone Frag- } \\
\text { ments }\end{array}$ & $\begin{array}{l}\text { Coal Resi- } \\
\text { due }\end{array}$ & $\begin{array}{l}\text { Metal (coin) } \\
\text { Fragments }\end{array}$ \\
\hline \multirow{3}{*}{$\mathrm{a}$} & $\mathrm{P}$ & 3 & 3 & - & - & - \\
\cline { 2 - 8 } & 1 & 43 & 6 & - & - & - \\
\cline { 2 - 8 } & 2 & 30 & 7 & 5 & - & - \\
\hline b & 3 & 11 & 1 & - & - & - \\
\cline { 2 - 8 } & 4 & 26 & - & - & $5 \mathrm{~g}$ & - \\
\cline { 2 - 8 } & 5 & 4 & - & - & - & - \\
\hline $\mathrm{d}$ & 24 & 1 & - & - & - & - \\
\hline \multicolumn{2}{l}{ Total } & 118 & 17 & 5 & $5 \mathrm{~g}$ & - \\
\hline
\end{tabular}

\section{Analysis of the Artefacts}

\section{Earthenware}

Earthenware fragments made up most finds at the Batu Gambir Site. None were found intact and the largest was a $25 \mathrm{~cm} \times 8 \mathrm{~cm}$ piece found at TP I, spit 11 at a depth of $115 \mathrm{~cm}$.

Most of the fragments were plain without any decorations except for the bearing of a circular indentation, probably from a natural cause in the making of the earthenware (see Table 3 below for items uncovered at Batu Gambir Site).

Table 3: Distribution of Earthenware Fragments at Batu Gambir Site

\begin{tabular}{|l|l|l|l|l|l|l|l|}
\hline Square & Lip & Rim & Neck & Carination & Body & Base & Amount \\
\hline TP I & 34 & 40 & 24 & 23 & 317 & 19 & 457 \\
\hline TP II & 13 & 13 & 6 & 11 & 75 & $1^{*}$ & 118 \\
\hline Total & 47 & 53 & 30 & 34 & 392 & 20 & 575 \\
\hline
\end{tabular}

Note: * a decorated earthenware fragment 
From the table above it can be seen that the earthenware fragments found at TP I amounted to 457 pieces, or 79,48 \%, and at TP II 118 pieces or 20,52\%. All were plain/unadorned $(99,83 \%)$ except for the piece found at TP II with a natural indentation similar to the one found at TP I/top soil.

Of the 575 fragments found, the largest percentage, 68,17\% or 392 pieces, were parts of the body. This was followed by the rim fragments $(9,21 \%)$ or 53 pieces, lip fragments $8,17 \%$ or 47 pieces, carination fragments 5,91 or 34 pieces, neck fragments $5,21 \%$ or 30 pieces, base fragments only $3,47 \%$ or 20 pieces. These proportions were consistent at both TP I and TP II.

From the fragments of the earthenware rims found and the orientation they had, analyses were made in order to reconstruct the types and function of the earthenware. Classification falls into two categories: the upright standing rim position, either with opened or closed rim, straight or bent shape. All were plain, with the exception of natural indentation occurring in the manufacturing process.

Analytical results from the 53 outer rim fragments taken from TP I and TP II are as follows:

Table 4: Distribution of Shapes and Orientation of Earthenware Rims

\begin{tabular}{|l|l|l|l|l|l|l|l|}
\hline \multirow{3}{*}{ Square } & \multicolumn{5}{|c|}{ Shape / Orientation } & \multirow{2}{*}{ Amount } \\
\cline { 2 - 7 } & \multicolumn{3}{|c|}{ Direct (straight) } & \multicolumn{3}{c|}{ Indirect (bent) } & \\
\cline { 2 - 7 } & Opened & Upright & Closed & Opened & Upright & Closed & \\
\hline TP I & 36 & - & - & 4 & - & - & 40 \\
\hline TP II & 11 & 1 & - & 1 & - & - & 13 \\
\hline Total & 47 & 1 & - & 5 & - & - & 53 \\
\hline
\end{tabular}

Based on the table above, we can identify five types of earthenware pottery at Batu Gambir Site:

a) Plate type: the largest straight plate with an outward opening rim has a diameter of $30 \mathrm{~cm}$ at the top; the others displayed approximately $20 \mathrm{~cm}-25 \mathrm{~cm}$ in diameter. They probably functioned as a serving dish rather than a dining dish; found at TP II, spit 4.

b) Bowl type: straight outward opening bowl with a diameter of $20 \mathrm{~cm}-30 \mathrm{~cm}$, with a much thicker lip compared to its main body. Found at both TP I and TP II. Straight outward opening bowls with opened or closed lips make up a large percentage of the artefacts found; there were also found straight upright bowls with opened lips. The bowl type accounted for most of the rim fragments found.

c) Basin type with carination: with indirectly opened rim (bent shape) and upright open lip. Diameter of the lips between $15 \mathrm{~cm}-30 \mathrm{~cm}$ and a width of the opening between $4 \mathrm{~cm}-7.5 \mathrm{~cm}$; found at TP I. 
d) Lid type: found only at TP II, bent form and open lip shape. Length and diameter cannot be identified from the sherd. The shape and the size of the body of the container to which the lid belonged could not be identified either.

e) Pitcher type: identified from the neck fragments found at TP II, with a diameter of $6 \mathrm{~cm}$. Pitchers were probably used instead of pots for storing water (no pots for storing water were found at Batu Gambir Site).

We can conclude from the Batu Gambir fragments themselves and from the fact that they were undecorated that these items were kitchen utensils. Drinking cups or pots were probably made from fragile materials that were easy to break, so that no remnants can be found.

Types of earthenware not found at Batu Gambir Site TP I or TP II: cups, jars, water pots, lamps, and legged bowls.

The result of technological analysis is as follows:

a) High velocity potter's wheels were used in the making of the pottery. This can be seen from parallel horizontal lines in the inner surface. The outside surface is usually smoothed out.

b) The raw material used was mostly clay of a red brownish colour mixed with coarse particles; pores are visible and consistent in both excavation sites. Sometimes fragments were found made from a finer material with a smoother texture, reddish in colour. In conclusion the raw materials consisted of: a) coarse mixture of clay and coarse sand that resulted in large particles and b) mixture of clay and quartz. Both components act as natural adhesives making the surface smooth and solid.

c) Outer surfaces were polished either by:

1) The slip method. This is done by covering the surface with the same mixture, with or without the same colouring. An example of this type was found at the Batu Gambir Site: one fragment had a red core and a black smooth surface.

2) The polish method. Evidence of this method can be found in a neck fragment where horizontal lines that covered the outer surface create a smooth and close surface.

From the analysis above, it can be said that the earthenware fragments were made by the people in the vicinity of todays Pacung, Sembiran or Julah, with the exception of the smooth neck fragment, which in all probability came from a different place of origin. 


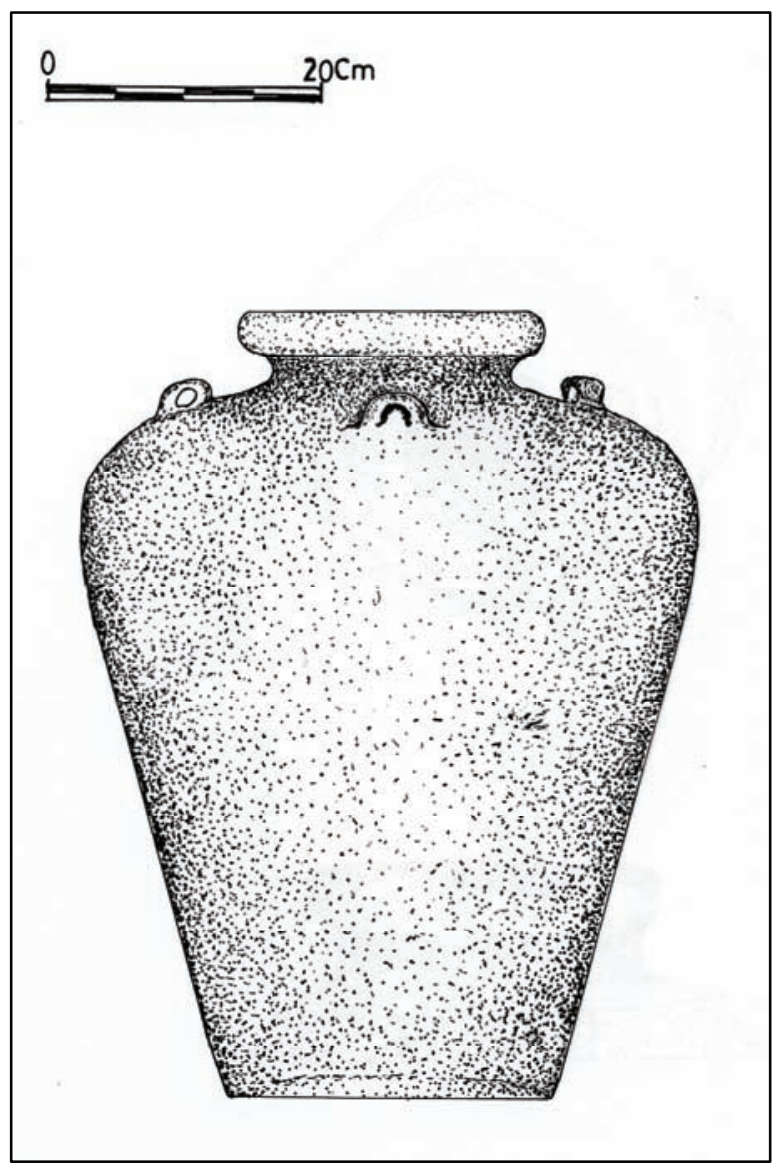

Figure 1: Drawing of a Chinese ceramic jar (Martavan type) found by a villager in Batu Gambir, Julah. Tim Jurusan Arkeologi 2005.

\section{Discovery of Chinese Ceramics}

Ceramics found in the Batu Gambir Site probably originated from China and were exchanged through commerce.

Dates when the ceramics were made can be analyzed from the type and motifs. Ceramic fragments found in TP I and TP II can be seen in the table below.

Table 5: Types of Ceramic Fragments at Batu Gambir Site

\begin{tabular}{|l|l|l|l|l|l|l|l|}
\hline Square & Lips & Rims & Neck & Carination & Body & Base & Amount \\
\hline TP I & - & 6 & - & 1 & 13 & 4 & 24 \\
\hline TP II & 6 & 1 & - & 1 & 9 & - & 17 \\
\hline Total & 6 & 7 & - & 2 & 22 & 4 & 41 \\
\hline
\end{tabular}


From a total of 41 pieces of fragments found, 22 pieces, or 53,7\%, are main body fragments, 7 pieces, or 17,1\%, rim fragments, 6 pieces, or 14,6\%, lip fragments, 4 pieces, or $9,8 \%$, base fragments and 2 pieces or $4,8 \%$ carination.

Based on the artefacts found (table 5) we can conclude that there were 3 types, their full shape in the Batu Gambir Site being as follows:

1) Plate type. Straight outward opening orientation; lips with a diameter between $20-30 \mathrm{~cm}$. Probably used for special purposes, not for everyday use, due to its beauty and luxurious quality and also economic value.

2) Bowl type. Straight, open orientation, diameter of the lips between $8-20 \mathrm{~cm}$ (found in both TP I and TP II). Variations of the bowl type can be seen in the form of the lips (opened and closed). There were also straight open, upright standing bowls with open lips. Bowls were apparently the most common ceramics found at the excavation site.

3) Small pot type (cepuk) found at spit 6 in TP I. Upright standing lip with a diameter of $8 \mathrm{~cm}$, a unique characteristic being that the lip part is thinner than the rest of the body. This is so that a lid can fit in; however, a lid could not be found.

Technical analysis shows two types of processes used in creating these objects:

1) Potter's wheel method: a characteristic of this type is that the base is not glazed, and parallel symmetrical grooves are visible.

2) Impressed technology: traces of this technique are visible on fragments that have parallel grooves in a wavy line.

Other analyses made were on the materials used and the method of glazing. It is noted that most were made from stoneware with a colouring of off-white, cream, grey or ivory, at its core and heated to a temperature of $1150-1300^{\circ} \mathrm{C}$. When made from porcelain, the inner part of the fragments has a milky or greyish white colour. It was heated to $1150-1350^{\circ} \mathrm{C}$. There are also two types of particles found: coarse and fine. Most of the fragments discovered have a fine texture.

The outer surface of these artefacts was glazed by either dipping each object into glaze liquid to make it shiny and transparent, with the exception of the base and the top of the lip.

Methods used to decorate the fragments were:

1) Paint: this is the most common decoration form. The surface of the ceramics was decorated by applying paint either with or without brush. The colour of the painted decoration differed from that of the glaze. The final colours became visible only after firing (under-glaze painting).

2) Application of the same material as used for the container on its surface.

3) Incision: incising with a sharp object on the surface until the desired picture is achieved. This method can be combined with the application method if the excised material is attached to an adjacent intact part of the surface to create a fur- 
ther decoration. There is one jar fragment that displays this method. It was used to create a dragon character (naga) with scales.

Almost all of the ceramic fragments found had some decoration except for 5 pieces. In TP I, 3 fragments were not decorated, 2 from the body and 1 from the rim. In TP II, only 2 fragments from the body were not decorated. Decoration consisted mostly of a single line, 2 parallel lines, dots, leaves, triangle, sunflower, bird wings, dragon scales and rising spirals. Judging from the variety and colour of raw materials, motifs, glaze and heated trace, the time and date of origin can be calculated for the different type of ceramic.

a) Sung Dynasty (between 960 and 1279 AD): off-white based, brown/iron-black glaze, stoneware; blue and white motifs with a bluish or rather greyish glaze; reddish or grey core. Leafs, twines and flowers as preferred decoration.

b) Yuan Dynasty (between 1279 and 1368 AD): off-white glazed, red lines on glazed base, reddish core.

c) Ming Dynasty (between 1368 and 1644 AD): blue and white motifs with vivid colours; greyish/shiny core; uneven dark-brown glaze. Application technique with motifs of dragon scales.

The ceramics with applications such as a dragon with scales and a dark-brown glaze may originate sometime between the $14^{\text {th }}$ and the $15^{\text {th }}$ century.

Wanli era (between 1572 and 1620 AD, that is Ming Dynasty): blue and white ceramic fragments from Swatow, featuring some faulty manufacture (International Field School of Archaeology 1991).

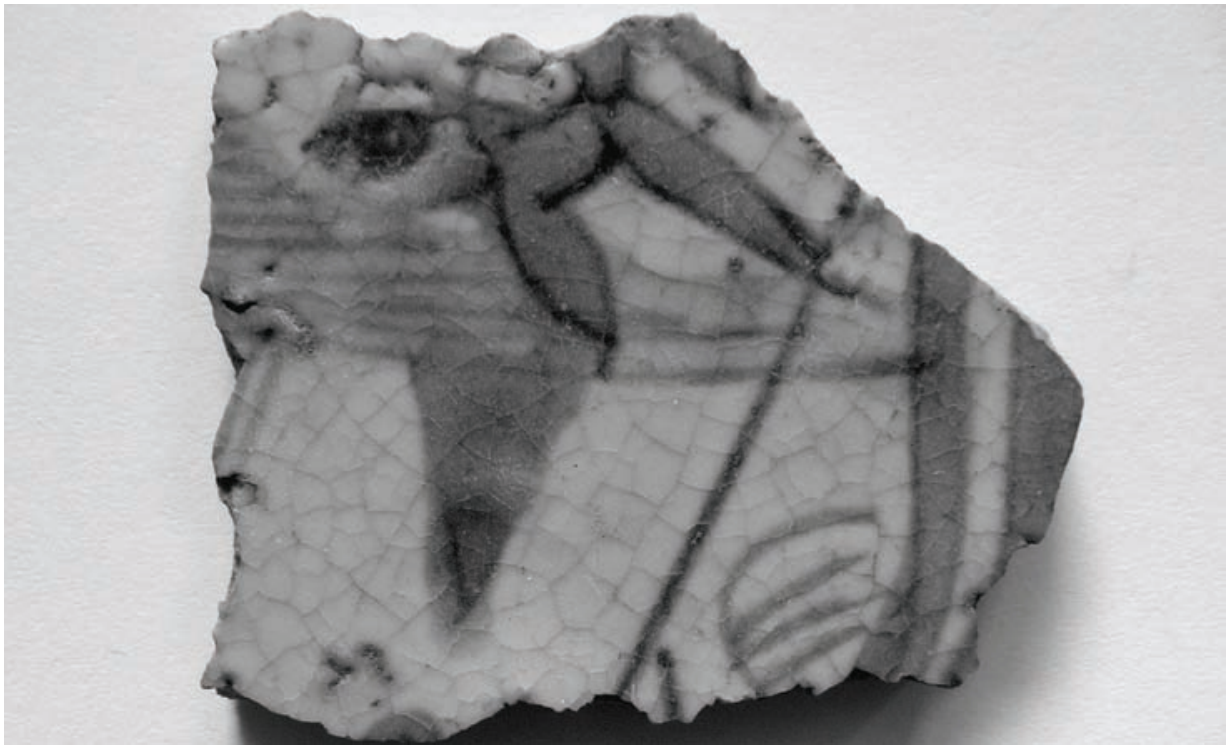

Photo 2: Chinese ceramic fragment found at the Batu Gambir Site. Photo: Jörg Hauser 2006. 


\section{Metal Fragments}

Two metal fragments of ancient Chinese coins were found in Batu Gambir Site at TP I/spit 6 (1 gram) and spit 8 (0.5 gram). Both were greenish in colour due to age. Difficult to verify origin or date, as the writings on the coins were blurred.

On the basis of these finds we can assume that the people of Old Julah, in the vicinity of Batu Gambir, were traders and used money, having progressed beyond the barter system.

Charcoal Residue

Charcoal was found in both TP I/spit 6 (2 g); spit 8 (20 g); spit 9 (2 g); and spit 11 $(2 \mathrm{~g})$; at TP II only at spit $4(5 \mathrm{~g})$. Total of 31 grams from both TP I and TP II.

\section{Organic Artefacts}

Remains of organism found at TP I and TP II consisted of bones and teeths. Further identification was difficult because of the fragile state.

At TP I spit 4 bone fragments $(2 \mathrm{~g})$; spit $6(1 \mathrm{~g})$; spit $8(1 \mathrm{~g})$; spit $9(1 \mathrm{~g})$; spit 10 $(2 \mathrm{~g})$ and at TP II spit 2 at lying close to another totalling 3 grams. Bone fragments at both TP I and TP II totalled 10 grams. In all probability they were animal bone fragments. Other organism artefacts found were two molar tooth fragments in TP II spit 2 (4 g), located close together.

With the findings of bones, tooth fragments and coal it can be stated that the people, at that time, consumed meat. Animals eaten by Old Balinese were pig, cattle, dogs, fish, and fowls (Archaeological Team of Udayana University 2004; 2005). These animals were not wild, but bred.

\section{Summary}

Findings at Batu Gambir Site were judged to be isolated or related artefacts and ecofacts. Most findings were fragments of earthenware. Types of earthenware were identified by rim fragments, fragments of plates, bowls, basins, jars and lids.

Other artefacts found were Chinese ceramics, which can be identified as to origin date and shape. Findings can be sorted into four groups: plates, bowls, box and jars calculated to be from the Sung, Yuan and Ming Dynasties that flourished between the $10^{\text {th }}$ and $16^{\text {th }}$ century. Artefacts that supported social interaction or commerce were the Chinese coins apparently used as a form of payment.

Ecofacts that suggested other activities were the findings of charcoal, bone, and teeth fragments from animals. The Julah people had a sophisticated coinage system used for commerce outside their community. The Batu Gambir Site was a characteristic "settlement" with its people probably making their living from farming and raising livestock. The evidence of money (coins) however, proves that the 
inhabitants of this settlement were integrated in an encompassing system of exchange and trade.

\section{References}

Archeological Team of Udayana University

2004 Ekskavasi Arkeologi di Situs Pacung, Tejakula Buleleng. Laporan Penelitian. Denpasar: Fakultas Sastra, Universitas Udayana.

2005 Ekskavasi Arkeologi di Situs Sembiran dan Pacung Kecamatan Tejakula Kabupaten Buleleng, Bali. Laporan Penelitian. Denpasar: Fakultas Sastra, Universitas Udayana.

Ardika, I Wayan

1988 Ekskavasi Arkeologi di Situs Pacung, Sembiran dan Julah. Kecamatan Tejakula, Buleleng. Laporan Penelitian. Denpasar: Fakultas Sastra, Universitas Udayana.

1991 Archaeological Research in Northeastern Bali. A Thesis Submitted for the Degree of Doctor of Philosophy at the Australian National University. Canberra: Australian National University.

Brandes, J.L.A.

1889 De koperen platen van Sembiran (Boeleleng, Bali): Oorkonden in het oudJavaansch en het oud-Balineesch. Tijdschrift voor Indische Taal-, Land- en Volkenkunde XXXIII. Batavia: Albrecht \& Rutche: 16-56.

Goris, R.

1954 Prasasti Bali. Lembaga Bahasa dan Budaya. Fakultas Sastra dan Filsafat, Universitas Indonesia. Bandung: Masa Baru.

International Field School of Archaeology

1991 Buku Panduan Keramik. Trowulan: Pusat Penelitian Arkeologi Nasional.

Santoso, Ida Bagus

1965 Prasasti-Prasasti Raja Anak Wungsu di Bali. Denpasar: Fakultas Sastra, Universitas Udayana.

Soejono, R.P.

1962 Preliminary Notes on New Finds of Lower Paleolithic Implements from Indonesia. Asian Perspectives V: 217 - 233.

Sutaba, I Made

1976 Megalitic Tradition in Sembiran North Bali. Aspek-aspek Arkeologi Indonesia, Vol. 4. Jakarta: Pusat Penelitian Arkeologi Nasional.

1980 Prasejarah Bali. Denpasar: Yayasan Purbakala Bali.

Poesponegoro, Marwati Djoened dan Nugroho Notonegoro

1984 Sejarah Nasional Indonesia I. Jakarta: PN Balai Pustaka.

Purbo-Hadiwidjojo, M.M.; H. Samodra and T.C. dan Amin

1998 Peta Geologi Lembar Bali, Nusa Tenggara. Skala 1 : 250.000. Bandung: Pusat Penelitian dan Pengembangan Geologi. 
Purbo-Hadiwidjojo

1971 Peta Hidrogeologi Tindjau Lembar Bali. Skala 1 : 250.000. Bandung: Direktorat.

Tim Jurusan Arkeologi

2005 Laporan Penelitian Ekskavasi Arkeologi di Situs Batu Gambir, Kecamatan Tejakula, Buleleng. Denpasar: Fakultas Sastra, Universitas Udayana. 